\title{
Profil hormon FSH, LH dan estradiol serta kadar glukosa darah sidat, Anguilla bicolor bicolor (Mc Clelland, 1844) yang dirangsang hormon HCG, MT, E2 dan anti dopamin
}

[Hormone profile of FSH, LH and estradiol with glucose blood level of Indonesian short-finned eel (Anguilla bicolor bicolor Mc Clelland, 1844) stimulated by HCG, MT, E2 and dopamine inhibitory]

\author{
Abdul Zahri ${ }^{1 凶}$, Agus Oman Sudrajat ${ }^{2}$, Muhammad Zairin Junior ${ }^{2}$ \\ ${ }^{1}$ Program Studi Budidaya Perikanan, Politeknik Perikanan Negeri Tual, Maluku Tenggara \\ ${ }^{2}$ Departemen Budidaya Perairan Fakultas Perikanan dan Ilmu Kelautan IPB
}

Diterima: 19 September 2017; Disetujui: 20 Februari 2018

\begin{abstract}
Abstrak
Penelitian ini bertujuan menganalisis profil hormon FSH, LH dan E2 ikan sidat yang dirangsang dengan hormon eksogenous serta kadar glukosa darah. Enam perlakuan diterapkan dengan kombinasi anti dopamin $10 \mathrm{mg} \mathrm{mL}^{-1}$ (A), estradiol (E2) $3 \mathrm{mg} \mathrm{mL}^{-1}+\mathrm{A}$ (EA), metyltestosteron (MT) $3 \mathrm{mg} \mathrm{mL}^{-1}+\mathrm{A}$ (MTA), hormon hCG $2 \mathrm{mg} \mathrm{mL} \mathrm{m}^{-1}+\mathrm{EA}$ (hEA) dan hCG $2 \mathrm{mg} \mathrm{mL}^{-1}+$ MTA (hMTA), dengan kontrol (F) fisiologis 0,9\% $\mathrm{NaCl}$. Enam kelompok sidat uji (200 $\left.\pm 15 \mathrm{~g}\right)$ dipelihara pada bak beton berkapasitas 3.400 liter dan di isi dengan air laut bersalinitas $35 \mathrm{mg} \mathrm{L}^{-1}$ sebanyak 2000 liter. Sidat diinjeksi dengan dosis hormon $1 \mathrm{~mL} \mathrm{~kg}^{-1}$ secara intramuskular, hewan uji diberi pakan secara at satiation sekali sehari selama 10 minggu. Penelitian menggunakan Rancangan Acak Lengkap dengan satu faktor perlakuan, yaitu faktor hormon dan kombinasinya. Darah sidat terbukti mengandung FSH, LH, E2, peningkatannya terlihat nyata terjadi melalui plasma darah pada perlakuan hMTA dan hEA pada tingkat $\mathrm{P}<0,05$. Konsentrasi glukosa tertinggi pada formula hMTA $67,33 \mathrm{mg} \mathrm{dL}^{-1}$ dan berbeda nyata pada taraf $\mathrm{P}<0,05$. Hasil ini menunjukkan bahwa penambahan hormon eksogenous perlakuan hMTA meningkatkan konsentrasi FSH, LH, dan E2. Profil FSH dan LH menunjukkan pola permutasi selama proses perkembangan gonad sidat, di mulai dengan meningkatnya FSH di fase awal perkembangan gonad. Profil LH bergerak seiring dengan peningkatan E2 selama proses pematangan gonad sidat (A. bicolor bicolor), dengan kadar glukosa darah pada kisaran normal.
\end{abstract}

Kata penting: glukosa, hormon, pematangan gonad, sidat

\begin{abstract}
This study aims to analyze the hormone profile of FSH, LH and $\mathrm{E}_{2}$ to the eel after exogenous hormone stimulation and blood glucose levels. Six formulated treatment applied with combination of dopamine antagonize $10 \mathrm{mg} \mathrm{mL}^{-1}$ (A), estradiol (E2) $3 \mathrm{mg} \mathrm{mL}^{-1}+\mathrm{A}$ (EA), metyltestosteron (MT) $3 \mathrm{mg} \mathrm{mL}^{-1}+\mathrm{A}$ (MTA), hCG $2 \mathrm{mg} \mathrm{mL}^{-1}+\mathrm{EA}$ (hEA) and hCG $2 \mathrm{mg} \mathrm{mL}^{-1}+$ MTA (hMTA), with (F) physiologis $0.9 \% \mathrm{NaCl}$ to control. Six group eel $(200 \pm 15 \mathrm{~g})$ reared in a concrete tank with a capacity of 3,400 liters and filled with sea water of $35 \mathrm{mg} \mathrm{L}^{-1}$ as much as 2000 liters. Eels injected $1 \mathrm{~mL} \mathrm{~kg}^{-1}$ hormone by intramusculary, were feed to apparent satiation daily for 10 weeks. The study used Completely Randomized Design with one treatment factor, namely hormonal factor and its combination. Fish blood that ware directly concentration to FSH, LH and E2, the enhanced significantly high in the blood plasma on treatment hMTA and hEA $\mathrm{P}<0.05$. Glucose concentration in the blood palsma is high enough in a row on a formula hMTA $67.33 \mathrm{mg} \mathrm{dL}^{-1}$ and significantly different to $\mathrm{P}<0.05$. The result indicates that induction of exogenous hormone (hMTA) improve FSH, LH and E2. FSH and LH profiles show permutation patterns during the development of eel gonad, beginning with the increase of FSH in the early phases of gonadal development. LH profile moves in line with the increase in E2 during gonadal maturation process eels (A. bicolor bicolor), with blood glucose levels in the normal range.
\end{abstract}

Keywords: glucose, hormone, gonad maturation, Indonesian short-finned eel.

\section{Pendahuluan}

Ikan sidat (Anguilla bicolor bicolor) bersifat katadromus, yaitu ikan yang melakukan ruaya pemijahan dari lingkungan air tawar ke lingkungan air laut dan umumnya terjadi pada

$\triangle$ Penulis korespondensi

Alamat surel: zalwie_25@yahoo.co.id malam hari. Sidat merupakan hewan yang aktif pada malam hari dan ruaya pemijahan umumnya dilakukan pada malam hari dan beristirahat pada siang harinya (Aerestrup et al. 2010). Telur menetas di laut dan larva sidat berenang kembali menuju perairan tawar untuk tumbuh menjadi sidat dewasa. Fahmi et al. (2013) dan Inoue et al. 
(2010) menjelaskan bahwa semua sidat hidup di air tawar dan kembali ke laut hanya untuk bertelur. Sampai saat ini, sidat juga digolongkan sebagai ikan yang melakukan pemijahan sekali dalam daur hidupnya, sehingga sangat penting untuk memastikan bahwa setidaknya terdapat sidat yang berhasil melakukan pemijahan untuk menjaga kelestarian sidat. Selain menjaga daur alamiahnya, menjaga kelestarian spesies dapat pula dilakukan dengan budi daya pada kondisi yang dimodifikasi dan terkontrol dengan rangsangan hormon.

Rangsangan hormon pada prinsipnya adalah upaya menambahkan sejumlah hormon dari luar (exogenous hormone) yang berfungsi sebagai kontrol proses reproduksi, sehingga daur reproduksi dapat dipercepat atau dapat dilakukan di luar lingkungan alamiahnya. Hormon penting yang mengatur proses reproduksi diantaranya adalah follicle stimulating hormone (FSH) dan luteinizing hormone ( $\mathrm{LH})$ yang disintesis di kelenjar hipofisis. Rangsangan dari lingkungan direspons oleh kelenjar pituitari (Weltzien et al. 2009), untuk mensintesis dan mensekresikan FSH dan LH (Cerda-Reverter \& Canosa 2009), yang merangsang gonad memproduksi hormonhormon steroid. Hormon ini berfungsi untuk mengatur kerja kelenjar gonad, FSH bertugas merangsang pertumbuhan follikel dan testis melalui proses spermatogenesis. LH merangsang pembentukan kuning telur dari minyak yang dihasilkan selama proses vitelogenesis hingga ovulasi serta meningkatkan produksi steroid hormon pada ikan betina dan jantan. Sebagaimana yang dijelaskan oleh Miura \& Miura (2011) dan Aroua et al. (2012), bahwa FSH menginisiasi gametogenesis dan vitelogenesis, sementara LH mengatur pematangan akhir, spermiasi dan ovulasi.
Proses perkembangan gonad yang dirangsang oleh hormon eksogenus mengakibatkan reaksi biologis spontan oleh tubuh sebagai respons terhadap dorongan untuk melakukan daur reproduksi. Reaksi biologis tubuh diantaranya berupa peningkatan kebutuhan energi untuk mempercepat perkembangan gonad. Kebutuhan energi juga dapat meningkat akibat stres karena perlakuan, tetapi stres akibat perlakuan dapat dikesampingkan bila diketahui bahwa penerapan hormon eksogenus efektif merangsang perkembangan gonad, sehingga energi yang dibutuhkan dalam bentuk glukosa dianggap sebagian terbesarnya digunakan untuk perkembangan gonad. Berdasarkan kadar glukosa darah dapat diketahui seberapa besar tingkat pemanfaatan energi untuk pertumbuhan gonad dan diketahui besarnya tingkat stres sidat selama perlakuan.

Pengukuran terhadap pergerakan konsentrasi hormon FSH dan LH dalam darah sidat dapat memberikan indikasi bahwa sidat telah termotivasi untuk melakukan reproduksi, dengan indikator profil hromon FSH, LH dan E2. Pengukuran konsentrasi glukosa dalam plasma darah juga dapat digunakan sebagai indikator adanya akselerasi terhadap pertumbuhan gonad dan linier dengan peningkatan profil hormon FSH dan LH. Profil hormon dapat dipicu oleh kondisi lingkungan (Kalujnaia et al. 2007) dan aktifitas estrogen (Tsai et al. 2011). Profil hormon A. anguilla menggambarkan pola peningkatan pada fase ruaya pemijahan (Van Ginneken et al. 2007).

Penelitian ini bertujuan menganalisis profil hormon FSH, LH dan E2 serta kadar glukosa darah sidat selama proses pematangan gonad yang dirangsang hormon hCG, metiltestosteron, estradiol, dan antidopamin secara tunggal maupun kombinasinya. Hasil penelitian ini diharapkan bermanfaat bagi perkembangan ilmu dan 
teknologi terapan untuk mendukung kegiatan budi daya sidat dalam lingkungan terkontrol.

\section{Bahan dan metode}

Penelitian dilaksanakan bulan Juli sampai Oktober 2014 di Kolam Percobaan Babakan, Departemen Budidaya Perairan, Fakultas Perikanan dan Ilmu Kelautan, Institut Pertanian Bogor. Bahan yang digunakan adalah ikan sidat dengan bobot $200 \pm 15$ g, masing-masing sebanyak 27 ekor per perlakuan. Sidat dipelihara di dalam bak berkapasitas 3 ton dengan air bersalinitas $35 \mathrm{mg}$ $\mathrm{L}^{-1}$ sebanyak 1,5 ton. Sidat diberi pakan pellet yang mengandung protein 46\% dengan ukuran butir pellet $3 \mathrm{~mm}$, pakan diberikan sehari sekali sampai kenyang.

Sidat diinjeksi dengan dosis $1 \mathrm{~mL} \mathrm{~kg}^{-1}$ berat tubuh secara intramuscular pada dasar sirip punggung. Sampling dan penyuntikan hormon dilakukan setiap dua minggu dengan frekuensi enam kali. Sebanyak 1,5 mL darah sidat diambil dan disentrifus dengan kecepatan 3500 rpm selama 3 menit, kemudian plasma darah dipindahkan ke tabung Eppendorf $1 \mathrm{~mL}$ dan disimpan beku pada suhu $-20{ }^{\circ} \mathrm{C}$. Konsentrasi hormon FSH, LH dan E2 dikuantifikasi menggunakan metoda enzyme-linked immunosorbent assay (ELISA). Instrumen yang digunakan yaitu ELISA reader Bio-Rad 550 pada panjang gelombang $450 \mathrm{~nm}$ dengan limit deteksi mulai dari $25 \mathrm{pg} \mathrm{mL}^{-1}$. Prosedur analisis ELISA mengikuti katalog produk spesifik E2 DRG ${ }^{\circledR}$ EIA-2693, FSH DRG ${ }^{\circledR}$ EIA- $^{-}$ 1288, LH DRG ${ }^{\circledR}$ EIA-1289, DRG International, USA.

Sampel serum beku dicairkan menggunakan heat cabinet selama 15 menit pada suhu $37^{\circ} \mathrm{C}$. Kit standar ditetapkan pada konsentrasi ber-tingkat, yaitu: 25, 50, 100, 250, 500, 1000 dan $2000 \mathrm{pg} \mathrm{mL} \mathrm{mL}^{-1}$. Sebanyak $100 \mu \mathrm{L}$ kit standar, kontrol dan sampel dipipet ke dalam masing- masing sumur microplate ELISA secara duplo, ditutup dan diberi label kemudian diinkubasi dua jam pada suhu $37{ }^{\circ} \mathrm{C}$. Selanjutnya ditambahkan $200 \mu \mathrm{L}$ enzim konjugat horse radish peroxidase ke dalam tiap sumur microplate dan diinkubasi selama 60 menit pada suhu $20-25{ }^{\circ} \mathrm{C}$. Setelah inkubasi, dilakukan pencucian dengan larutan wash solution $400 \mu \mathrm{L}$ tiap-tiap sumur. Sebanyak $100 \mu \mathrm{L}$ larutan substrat ditambahkan pada tiap sumur dan diinkubasi selama 15-30 menit pada suhu $37{ }^{\circ} \mathrm{C}$. Sampai tahap ini microplate harus dilindungi dari cahaya langsung. Stop solution yang mengandung 0,5 mol $\mathrm{H}_{2} \mathrm{SO}_{4}$ ditambahkan pada tiap-tiap sumur sebanyak $50 \mu \mathrm{L}$ untuk menghentikan reaksi enzimatik. Kerapatan optik dari setiap sumur ditetapkan dan pembacaan lempeng diatur pada panjang gelombang $450 \mathrm{~nm}$ selama 10 menit menggunakan ELISA reader BioRad 550.

Konsentrasi glukosa darah dianalisis menggunakan glukosa accu-check, dengan cara kertas strip dimasukkan kedalam lubang accucheck tunggu beberapa saat hingga layar monitor menampilkan pilihan komponen satuan darah (mmol L $\mathrm{L}^{-1}$ atau $\mathrm{mg} \mathrm{dL}^{-1}$ ). Darah diteteskan pada kertas strip yang telah terpasang pada accucheck, ditunggu hingga monitor menampilkan hasilnya sesuai dengan satuan yang dipilih. Menurut Bartonkova et al. (2016), pengukuran kadar glukosa menggunkana glucometer kit lebih mudah dan cepat dengan hasil yang tingkat ketelitiannya tidak jauh berbeda dengan metode konvensional seperti spektrofotometer.

Penelitian menggunakan rancangan acak lengkap dengan satu faktor perlakuan, yaitu hormon secara tunggal dan kombinasinya. Perlakuan terdiri atas enam faktor perlakuan dan tiap perlakuan diulang sebanyak tiga kali. Perlakuan yang digunakan diantaranya anti dopamin (A) $10 \mathrm{mg}$ $\mathrm{mL}^{-1}$, eastradiol (E) $3 \mathrm{mg} \mathrm{mL}{ }^{-1}$, metiltestosteron 
(MT) $3 \mathrm{mg} \mathrm{mL} \mathrm{mL}^{-1}$, human chorionic gonadotropin (hCG) $20 \mathrm{IU} \mathrm{mL} \mathrm{m}^{-1}$, dan larutan fisiologis $0,9 \%$ $\mathrm{NaCl}$.

Parameter yang diamati yaitu profil konsentrasi hormon FSH, LH, Estradiol dan kadar glukosa darah. Data dianalisis menggunakan sidik ragam dan beda nilai tengah perlakuan diuji menggunakan uji Beda Nyata Terkecil.

\section{Hasil}

Profil hormon FSH, LH, dan E2

Profil hormon reproduksi yang menjadi

F

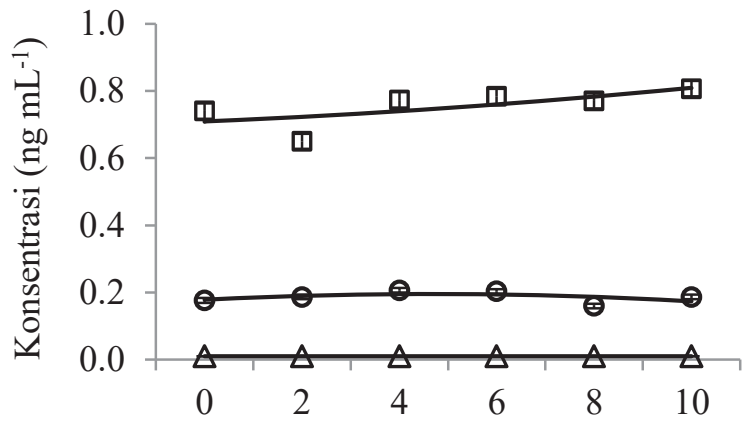

EA

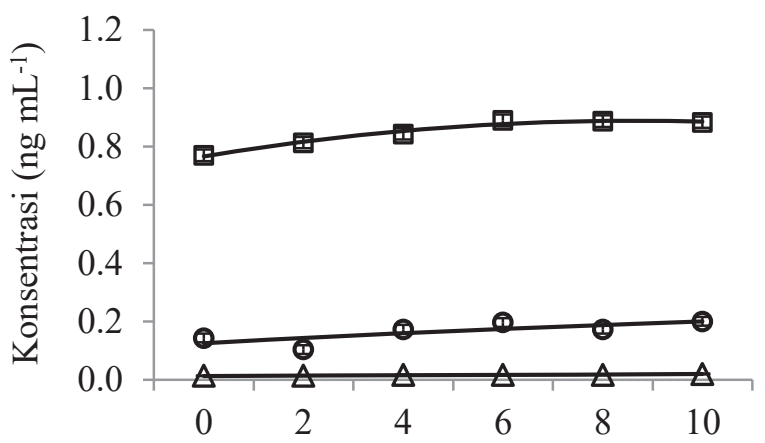

\section{hEA}

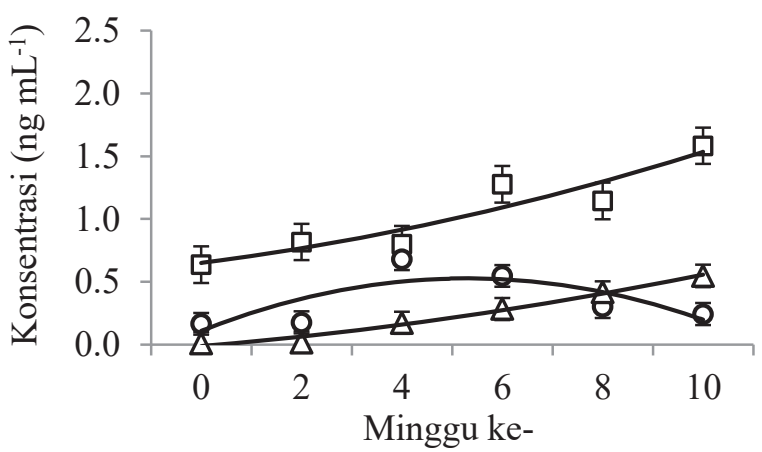

parameter uji dalam penelitian ini adalah hormon, FSH, LH, dan E2. Adapun nilai tengah profil konsentrasi hormon FSH, LH, dan E2 setiap perlakuan dari minggu ke-0 sampai minggu ke10 sebagaimana tertera pada Gambar 1. Gambar tersebut menunjukkan bahwa perlakuan hormon hEA dan hMTA meningkatkan konsentrasi hormon FSH, LH, dan E2. FSH meningkat secara drastis di minggu ke-4 dan secara teratur turun sampai akhir penelitian. Estradiol meningkat secara teratur dan paralel dengan LH mulai minggu ke-2 sampai minggu ke-10.

A

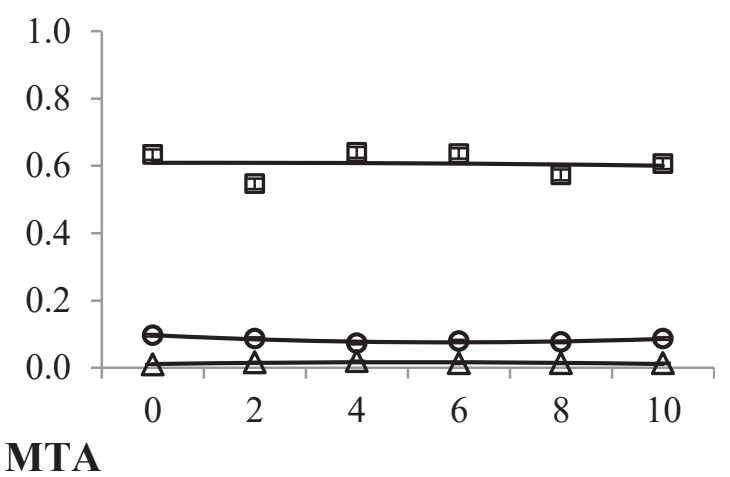

MTA

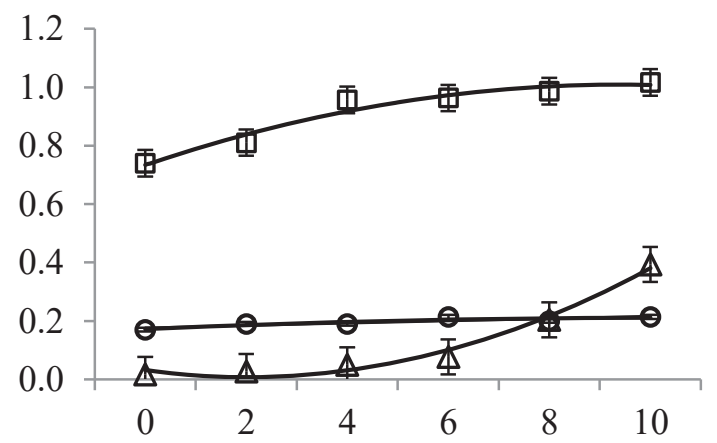

hMTA

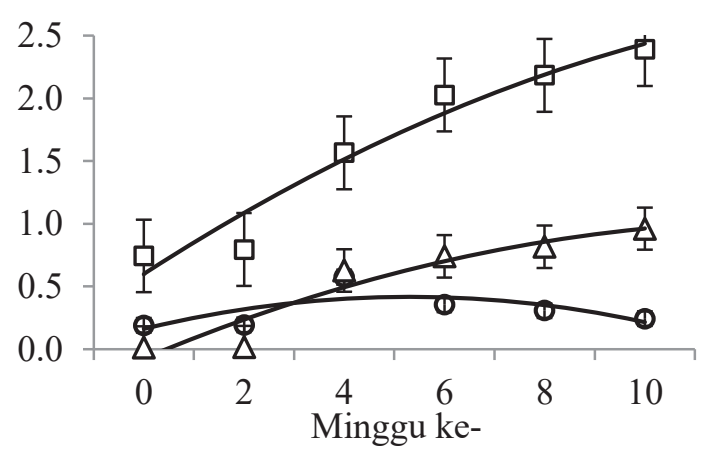

Gambar 1. Nilai tengah profil hormon FSH (०), LH (๑) dan E2 ( $\square)$ Anguilla bicolor bicolor selama perlakuan. F: kontrol, A: anti dopamin, EA: estradiol + A, MTA: metiltestosteron + A, hEA: hCG + E2 + A, hMTA: hCG + MT + A. FSH, LH dan E2 dikuantifikasi menggunakan ELISA dengn tingkat kepekaan $\geq 25 \mathrm{pg} \mathrm{mL}^{-1}$. 
$\mathbf{F}$

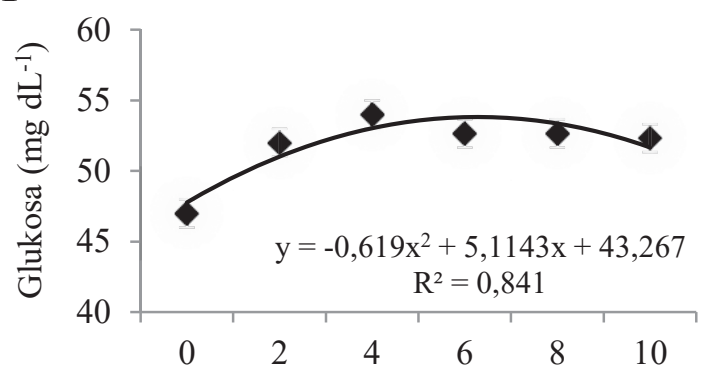

EA

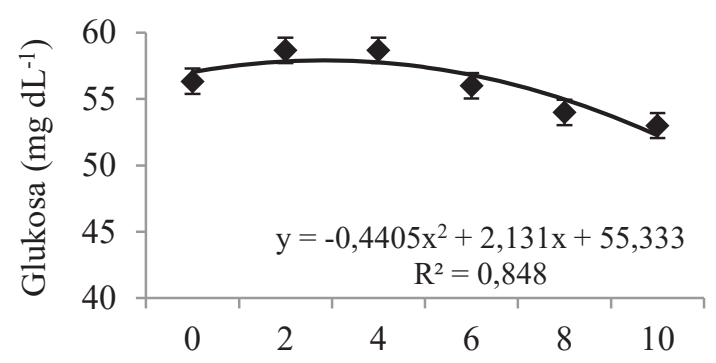

hEA

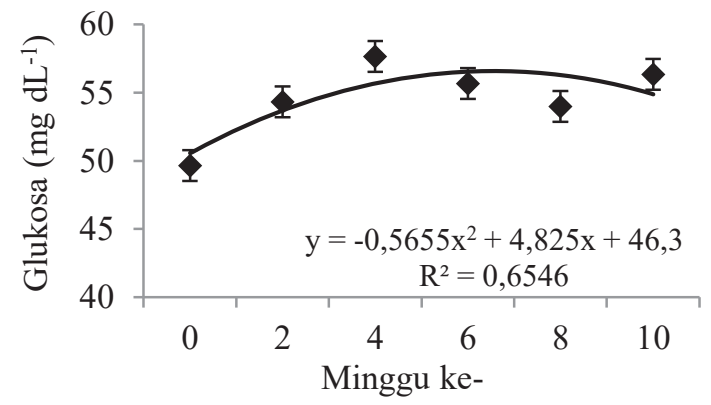

A

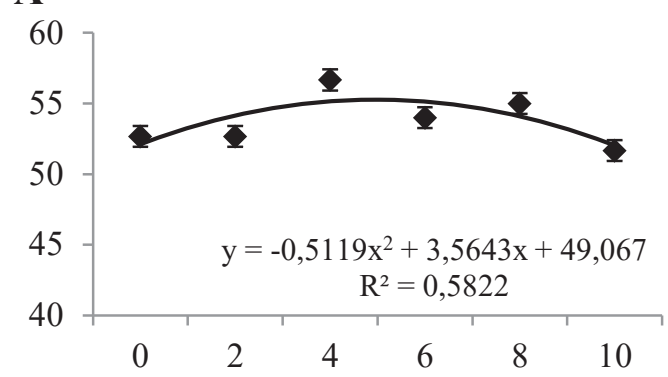

MTA

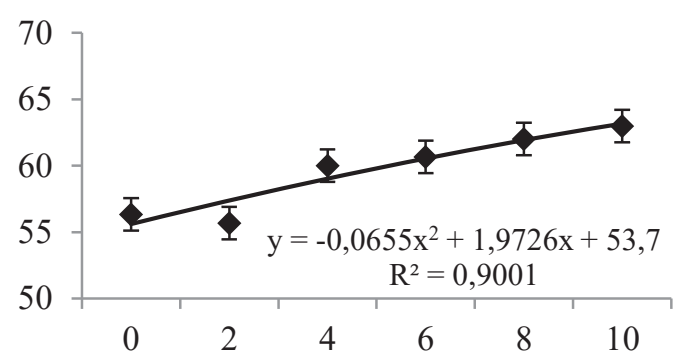

hMTA

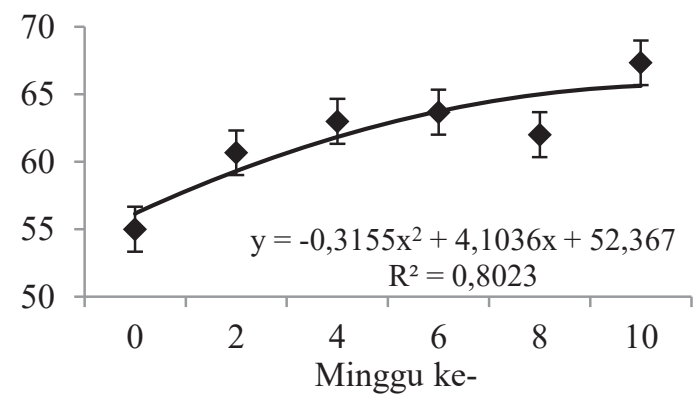

Gambar 2. Nilai tengah kadar glukosa darah sidat Anguilla bicolor bicolor selama perlakuan. F: kontrol, A: anti dopamin, EA: estradiol + A, MTA: metiltestosteron + A, hEA: hCG + E2 + A, hMTA: $\mathrm{hCG}+\mathrm{MT}+\mathrm{A}$. Kadar glukosa dikuantifikasi menggunakan instrumen glukosa accu-check dengan satuan $\mathrm{mg} \mathrm{dL} \mathrm{L}^{-1}$.

Kadar glukosa darah sidat

Glukosa merupakan salah satu sumber energi dan merupakan bahan bakar penting untuk metabolisme sel, termasuk sel-sel otak dan gonad. Selama proses pertumbuhan dan pematangan gonad, otak memegang peranan penting untuk menerima sinyal eksternal dan meneruskannya ke organ target dalam bentuk neurotransmiter maupun neurohormon, dan proses ini memerlukan energi yang bersumber dari glukosa. Kadar glukosa yang terdeteksi dalam darah sidat seperti tertera pada Gambar 2.

\section{Pembahasan}

Gambar 1 memberikan informasi tentang interaksi antara pengaruh perlakuan terhadap profil serum hormon FSH, LH, dan E2. FSH dan LH disekresikan oleh kelenjar hipofisis untuk mengatur reproduksi, dengan tingginya konsentrasi serum hormon ini dalam darah sidat menunjukkan bahwa sidat telah terangsang untuk melakukan proses reproduksi. Konsentrasi serum FSH tertinggi terdapat pada perlakuan hMTA $0,31 \pm$ $0,14 \mathrm{ng} \mathrm{mL}^{-1}$ dan perlakuan hEA $0,36 \pm 0,20$ 
ng $\mathrm{mL}^{-1}$ dengan determinasi keragaman 0,5184 atau 51,84\% menunjukkan bahwa garis dugaan dari percobaan yang diterapkan mendekati kondisi sebenarnya. Terdapat perbedaan pada perlakuan hEA dan hMTA terhadap perlakuan lainnya pada taraf $\mathrm{P}<0,01$. Perlakuan MTA berbeda nyata terhadap perlakuan EA, A dan F pada taraf $\mathrm{P}<0,05$.

Penerapan hormon secara kombinasi lebih baik untuk tujuan mempercepat rangsangan reproduksi, karena tiap-tiap hormon yang diterapkan berkontribusi sesuai dengan fungsinya masing-masing dalam membangun sinergi. Perlakuan terbaik dalam penelitian ini adalah kombinasi antara hCG, MT dan AD. Hasil penelitian ini identik dengan penelitian lain yang menggunakan kombinasi hormon mampu meningkatkan konsentrasi LH dalam plasma darah mencapai 5 ng $\mathrm{mL}^{-1}$ (Vidal et al. 2004 in Weltzien et al. 2009). Penerapan hCG dimaksudkan untuk menggantikan peran hipofisis menyekresikan FSH dan LH apabila tidak mendapat cukup rangsangan oleh anti dopamin. Dampak melimpahnya FSH dan LH di dalam darah sidat, direspons oleh gonad dengan menyintesis dan melepaskan testosteron dan E2. Sementara itu, adanya tambahan hormon eksternal memberikan pesan kepada gonad untuk mempertegas status kelamin, jantan atau betina. Ketegasan status kelamin sangat membantu mempercepat proses spermatogenesis dan oogenesis serta pematangan akhir, karena status kelamin berpengaruh terhadap seluruh fungsi-fungsi reproduksi. Kontras dengan temuan Kasuga et al. (2008) pada A. japonica dan Tomkiewicz et al. (2011) pada A. Anguilla bahwa hCG lebih menginduksi spermatogenesis dan tidak demikian pada oogenesis.

Testosteron dapat ditransformasi menjadi E2 dengan bantuan aromatase yang mengarah pada pembetinaan dan vitelogenesis. Pernyataan ini menjelaskan mengapa pada perlakuan hMTA memiliki profil hormon reproduksi dengan nilai rata-rata lebih tinggi daripada perlakuan hEA. Terdapat dua tahapan penting pada kasus ini, pertama sintesis precursor steroid dari testosterone menjadi hidroksiprogesteron, kedua dengan bantuan aromatase dikonversi menjadi estradiol yang dapat digunakan untuk perkembangan gonad (Nagahama \& Yamashita 2008). Piferrer \& Blázquez (2006) dan kemudian Uno et al. (2012) menegaskan bahwa aromatase juga berfungsi menentukan perubahan kelamin dan orientasi lingkungan. Meningkatnya konsentrasi E2 mengakibatkan terjadinya rangsangan yang kuat terhadap proses vitelogenesis, yang efeknya mempercepat aktifitas perkembangan gonad. Hakikatnya, dengan melimpahnya hormon reproduksi eksogenous yang berasal dari perlakuan dapat memberikan sinyal dimulainya reproduksi kepada sistem biologis tubuh untuk merangsang poros otak-hipotalamus-pituitari-gonad aktif menyekresikan hormon endogenous untuk mempercepat pendewasaan seksual dan daur reproduksi.

Hormon FSH dan LH meningkat secara drastis di minggu ke-4 pada perlakuan hEA dan hTMA, dan efeknya terjadi percepatan pertumbuhan folikel. Bersamaan dengan pertumbuhan folikel, maka gonad dirangsang untuk menyintesis estradiol dan konsentrasinya terus meningkat seiring dengan tingkat perkembangan gonad. Sementara itu, meningkatnya E2 memberikan umpan balik positif terhadap poros otak-hipotalamus-pituitari untuk menyintesis LH. Kondisi ini terbukti dengan semakin meningkatnya konsentrasi LH dan seiring dengan peningkatan konsentrasi E2. Pada saat yang bersamaan, meningkatnya E2 juga menjadi umpan balik negatif terhadap sekresi FSH dan konsentrasinya mengalami penurunan setelah mencapai puncaknya di minggu ke-4. Sidat fase silver ditemukan hanya 
menyintesis dan melepaskan LH seiring dengan peningkatan E2, tetapi FSH tidak terdeteksi (Schmitz et al. 2005 in Weltzien et al. 2009) dan estrogen dapat merangsang peningkatan sintesis dan sekresi LH yang pengaturannya pada banyak jenis ikan dikontrol oleh dopamin (Yaron \& Levavi-Sivan 2011).

Terdapat perbedaan nyata antara konsentrasi E2 pada perlakuan hEA dengan hMTA pada taraf $\mathrm{P}<0,05$. Pada perlakuan hEA konsentrasi E2 1,58 $\mathrm{ng} \mathrm{mL}^{-1}$ dan hMTA 2,39 $\mathrm{ng} \mathrm{mL}^{-1}$. Fenomena ini dimungkinkan karena keberadaan E2 tidak semata didapat dari luar, tetapi juga dihasilkan dari dalam tubuh, yaitu sekresi E2 oleh gonad. Indikatornya adalah meningkatnya konsentrasi LH, sehingga tingginya konsentrasi E2 pada perlakuan hEA dan hMTA disebabkan oleh peningkatan konsentrasi LH dan bukan karena E2 eksogenous. Profil konsentrasi estradiol pada penelitian ini memiliki pola yang serupa dengan sidat eropa, A. anguilla yang ditangkap di alam (van Ginneken et al. 2007a). Percobaan daya renang yang dilakukan pada $A$. anguilla terhadap tingkat kematangan seksual menunjukkan bahwa konsentrasi LH memiliki korelasi yang sangat kuat terhadap konsentrasi E2 dan peran FSH tidak dominan selama proses perkembangan gonad kecuali pada fase paling awal (van Ginneken et al. 2007) demikian pula pada A. japonica yang sedang melakukan ruaya pemijahan (Sudo et al. 2011).

Kondisi yang serupa terjadi pula pada perlakuan hEA. Fenomena seperti ini menunjukkan telah terjadi sintesis dan pelepasan hormon oleh kelenjar pituitari maupun gonad. Peningkatan konsentrasi E2 merupakan respons dari peningkatan LH, dengan demikian merupakan umpan balik negarif terhadap sekresi FSH. Pergerakan FSH yang ditampilkan oleh Gambar 1 perlakuan hEA dan hMTA menunjukkan adanya pe- ningkatan pada awal perlakuan sampai minggu ke-4 kemudian diiringi dengan penurunan yang teratur hingga minggu ke-10, yaitu saat meningkatnya konsentrasi LH.

Pada kelompok ikan salmon, konsentrasi FSH meningkat selama perkembangan gonad dan turun sampai saat pematangan. Kadar LH sangat rendah saat perkembangan awal daur reproduksi, kemudian meningkat selama periode akhir pematangan (Suetake et al. 2003). Sementara itu, penelitian yang dilakukan pada $A$. japonica menunjukkan pola peningkatan sekresi FSH selama masa vitelogenesis hingga 15 kali dari kontrol dan LH hanya 1,5 kali. Sekresi FSH ditekan seiring meningkatnya LH. FSH tidak memberikan efek apapun pada A. japonica yang telah mencapai tahap pematangan (Ishihara et al. 2011, Miura \& Miura 2011, Aroua et al. 2012).

Konsentrasi LH juga terlihat meningkat pada perlakuan MTA dan berdasarkan analisis ragam berpengaruh nyata $\mathrm{P}<0,05$. Pergerakan konsentrasi serum LH pada awal perlakuan relatif serupa dengan perlakuan hEA, yaitu dimulai pada minggu ke-2 dengan konsentrasi 0,03 ng $\mathrm{mL}^{-1}$ setelah penyuntikan hormon dan perlahan meningkat sampai minggu ke-6 0,08 ng $\mathrm{mL}^{-1}$. Peningkatan tinggi terjadi pada minggu ke- 8 de-

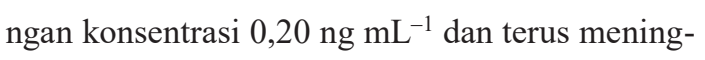
kat sampai minggu ke-10 dengan konsentrasi $0,39 \mathrm{ng} \mathrm{mL}-1$. Tinginya serum LH berimplikasi pada peningkatan perkembangan gonad dan dengan adanya MT mengarah pada penjantanan. Hormon LH berperan merangsang Leydig sel untuk menghasilkan hormon testosteron. Testosteron aktif merangsang sel-sel sertoli sebagai mediator pertumbuhan gonad. Studi yang dilakukan pada berbagai jenis ikan teleost menunjukkan bahwa LH turut berperan aktif merangsang selsel folikel (Nagahama \& Yamashita 2008). Anti dopamin juga memiliki peran penting pada kon- 
trol pelepasan LH dan perkembangan gonad pada banyak yuwana ikan teleost (Weltzien et al. 2009, Yaron \& Levavi-Sivan 2011). Meskipun peran FSH sangat kecil pada perkembangan gonad sidat, secara umum Lubzens \& Cerda (2010) berpendapat bahwa FSH, LH, dan E2 masingmasing berperan sangat penting selama fase perkembangan gonad hingga pematangan dan ovulasi.

Meningkatnya aktifitas biologis tubuh, selalu diimbangi dengan meningkatnya kadar glukosa darah. Gambar 2 menampilkan variasi ratarata kadar glukosa darah sidat tiap perlakuan. Kadar glukosa darah sidat pada perlakuan F dan A memiliki pola yang serupa yaitu adanya peningkatan yang realatif kecil dan berfluktuasi. Pada perlakuan EA kadar glukosa darah meningkat hingga minggu ke-4, kemudian mengalami penurunan hingga minggu ke-10. Kadar glukosa darah yang lebih tinggi dan terus mengalami peningkatan terlihat pada perlakuan MTA, hEA, dan hMTA. Nilai tengah kadar glukosa darah sidat terendah terdapat pada kontrol 47,55 mg $\mathrm{dL}^{-1}$, sedangkan tertinggi pada perlakuan hMTA $67,33 \mathrm{mg} \mathrm{dL}^{-1}$.

Variasi nilai tengah kadar glukosa darah sidat terhadap ragam perlakuan membentuk pola persamaan garis polinomial. Pola gambar menunjukkan bahwa terdapat keragaman tinggi dari pengaruh perlakuan hormon (X) terhadap variasi nilai tengah kadar glukosa darah (Y) 1,8952 mg $\mathrm{dL}^{-1}$. Nilai determinasi di atas 50\% menunjukkan bahwa garis dugaan dari percobaan yang dilakukan mendekati kondisi sebenarnya sebesar $75,75 \%$. Kadar glukosa darah sidat masih pada batas normal. Penelitian yang dilakukan terhadap ikan cyprinid menunjukkan bahwa kadar glukosa normal berkisar antara 40-90 $\mathrm{mg} \mathrm{dL}^{-1}$ (Patriche, 2009) dan 40-80 $\mathrm{mg} \mathrm{dL}^{-1}$ pada ikan zebra, Danio rerio (Eames et al. 2010).
Glukosa merupakan sumber energi penting untuk metabolisme sel, termasuk sel-sel otak dan gonad. Selama proses pertumbuhan dan pematangan gonad, otak memegang peranan penting dalam menerima sinyal eksternal dan meneruskannya ke organ target dalam bentuk neurotransmiter maupun neurohormon, dan proses ini memerlukan energi yang bersumber dari glukosa. Meningkatnya aktifitas biologis tubuh, diimbangi dengan meningkatnya pasokan glukosa. Sampai batas tertentu, tingginya metabolisme dapat meningkatkan kadar glukosa darah (Martinez-Porchas et al. 2009, Volkoff et al. 2009). Ikan sidat yang telah memulai proses ruaya pemijahan, sebagian besar energinya disimpan untuk proses perkembangan gonad; sedangkan sisanya yaitu sekitar $40 \%$ digunakan selama menempuh perjalanan menuju lokasi pemijahan (Van Ginneken \& van den Thillart 2000 in Van Ginneken et al. 2007b).

Meningkatnya aktifitas sel-sel otak menyintesis dan menyekresikan hormon FSH dan LH serta sintesis estradiol di gonad membutuhkan sejumlah energi yang berasal dari glukosa. Indikasi ini tergambar dari meningkatnya kadar glukosa darah pada perlakuan hMTA yang diikuti oleh meningkatnya konsentrasi hormon. Keseimbangan pemanfaatan energi untuk proses reproduksi dan menunjang aktifitas tubuh lainnya diatur oleh insulin dan glukagon, sedangkan metabolismenya melalui proses glikogenolisis dan glukoneogenesis (Aronof et al. 2004, Volkoff et al. 2009, Tubio et al. 2010).

Sidat merupakan ikan karnivora sehingga sumber glukosa sebagian besar berasal dari bahan selain karbohidrat. Melalui proses glukoneogenesis substrat seperti asam amino dan gliserol dapat disintesis menjadi glukosa. Insulin disekresikan sebagai respons terhadap meningkatnya kadar glukosa darah dan merangsang hati menyim- 
pan glukosa sebagai cadangan dalam bentuk glikogen dan lebih mudah digunakan oleh jaringan yang membutuhkan. Turunnya kadar glukosa darah merupakan sinyal untuk menyintesis dan menyekresikan glukagon. Dengan demikian mekanisme produksi glukosa melalui proses glikogenolisis maupun glukoneogenesis di hati meningkat dan membebaskan glukosa ke dalam darah yang siap digunakan oleh otak untuk menghasilkan FSH dan LH serta gonad untuk menyintesis dan menyekresikan estradiol.

Parameter kualitas air yang diukur selama masa penelitian diantaranya suhu, salinitas, $\mathrm{pH}$, dan oksigen terlarut. Pengukuran dilakukan setiap dua hari sekali dengan fluktuasi kualitas air selama penelitian tercatat dalam kisaran normal, suhu $26-28^{\circ} \mathrm{C}$, salinitas $35-37 \mathrm{mg} \mathrm{L}^{-1}, \mathrm{pH} 7,6-$ 7,7 , dan oksigen terlarut $6,2-7,3 \mathrm{mg} \mathrm{L}^{-1}$. Salinitas sengaja dikondisikan sedikit lebih tinggi daripada kisaran hidup sidat secara alamiah, yaitu 30-33 mg L ${ }^{-1}$. Pengkondisian salinitas di atas kisaran normal hidup sidat ternyata mampu memberikan pengaruh terhadap perkembangan gonad A. bicolor bicolor. Kondisi ini telah diterapkan pada sidat Eropa A. anguilla selama spermatogenesis dengan rangsangan hormon pada salinitas 35-36 mg L ${ }^{-1}$ (Tomkiewicz et al. 2011, Butts et al. 2014) sedangkan A. dieffenbachii pada salinitas 29-33 mg L L $^{-1}$ Lokman et al. 2001).

\section{Simpulan}

Perlakuan hormon MTA, hEA dan hMTA mampu meningkatkan konsentrasi FSH, LH dan E2 selama fase perkembangan gonad sidat. Profil FSH meningkat diawal fase perkembangan gonad sampai puncaknya pada minggu ke-4 perlakuan, kemudian turun secara perlahan. Profil LH meningkat secara bertahap mulai dari minggu ke2 hingga minggu ke-10 yang diikuti pula oleh peningkatan E2. Kadar glukosa darah sidat terpan- tau masih dalam kisaraan normal. Di antara semua perlakuan, hMTA memiliki kinerja terbaik terhadap peningkatan profil FSH, LH dan E2 selama fase perkembangan gonad sidat.

\section{Persantunan}

Terimakasih penulis sampaikan kepada kepada Balai Layanan Usaha Pengembangan Perikanan Budidaya (BLUPPB) Karawang atas bantuan menyediakan ikan sidat. Sebagian pembiayaan dalam penelitian ini diperoleh dari program BPPS 2011 Kementerian Riset, Teknologi dan Pendidikan Tinggi Republik Indonesia.

\section{Daftar pustaka}

Aarestrup K, Thorstad EB, Koed A, Svendsen JC, Jepsen N, Pedersen MI, Økland F. 2010. Survival and progression rates of large European silver eel Anguilla anguilla in late freshwater and early marine phases. Aquatic Biology, 9(1): 263-270.

Aronoff SL, Berkowitz K, Shreiner B, Want L. 2004. Glucose metabolism and regulation: beyond insulin and glucagon. Diabetes Spectrum; 17, 3; pg. 183.

Aroua S, Maugars G, Jeng SR, Chang CF, Weltzien FA, Rousseau K, Dufour S. 2012. Pituitary gonadotropins FSH and LH are oppositely regulated by the activin/follistatin system in a basal teleost, the eel. General and Comparative Endocrinology, 175(1): 82-91.

Bartoňková J, Hyršl P, Vojtek L. 2016. Glucose determination in fish plasma by two different moderate methods. Acta Veterinární Brno. 85(1): 349-353.

Butts IAE, Sørensen SR, Politis SN, Pitcher TE, Tomkiewicz J. 2014. Standardization of fertilization protocols for the European eel, Anguilla anguilla. Aquaculture. 426427: 9-13.

Cerda-Reverter JM, Canosa LF. 2009. Neuroendocrine System of the Fish Brain. In: Bernier NJ, Farrell AP, van der Krak G, Brauner CJ. (Eds.). Fish Physiology, 28: Fish Neuroendocrinology. Academic Press, London (UK). pp. 3-74. 
Eames SC, Philipson LH, Prince VE, Kinkel MD. 2010. Blood sugar measurement in zebrafish reveals dynamics of glucose homeostasis. Zebrafish, 7(2): 205-213.

Fahmi MR, Solihin DD, Soewardi K, Pouyaud L, Shao Z, Berrebi P. 2013. A novel semimultiplex PCR assay for identification of tropical eels of genus Anguilla in Indonesia waters. Fisheries Science. 79(2): 185191

Inoue JG, Miya M, Miller MJ, Sado T, Hanel R, Hatooka K, Aoyama J, Minegishi Y, Nishida M, Tsukamoto K. 2010. Deep-ocean origin of freshwater eels. Biology Letters, 6(3): 363-366.

Ishihara M, Abe T, Kazeto Y. Ijiri S, Adachi S. 2011. Effects of gonadotropic hormone on the acquisition of ovulatory competence in Japanese eel Anguilla japonica and bester sturgeon (Huso huso $\times$ Acipenser ruthenus). Indian Journal Science Technology. Proceedings of $9^{\text {th }}$ International Symposium on Reproductive Physiology of Fish, Cochin, India, 4(S8): 223-224.

Kalujnaia S, McWilliam IS, Zaguinaiko VA, Feilen AL, Nicholson J, Hazon N, Cutler CP, Balment RJ, Cossins AR, Hughes M, Cramb G. 2007. Salinity adaptation and gene profiling analysis in the European eel (Anguilla anguilla) using microarray technology. General and Comparative Endocrinology, 152(1): 274-280

Kasuga Y. Adachi J, Nishi A, Hashimoto H, Kaji S, Horiuchi Y, Kagawa H. 2008. Induction of sexual maturation of male Japanese eel (Anguilla japonica) by continuous administration of various hormones using osmotic pump. Cybium, 32(2) suppl.: pg. 171.

Lokman PM, Wass RT, Sutter HC, Scott SG, Judge KF, Young G. 2001. Changes steroid hormone profiles and ovarian histology during salmon pituitary-induced vitellogenesis and ovulation in female New Zealand longfinned eels, Anguilla dieffenbachia Gray. Journal of Experimental Zoology. 289(1): 119-129.

Lubzens E, Cerda J. 2010. Oogenesis in teleost: how fish eggs are formed. General and Comparative Endocrinology, 10(3): $367-$ 389.

Miura C, Miura T. 2011. Analysis of spermatogenesis using an eel model. Aqua-Bio-
Science Monographs (ABSM), 4(4): 105129.

Martínez-Porchas M, Martínez-Córdova LR, Ramos-Enriquez R. 2009. Cortisol and glucose: reliable indicators of fish stress? Pan-American Journal of Aquatic Science. 4(2): 158-178.

Nagahama Y, Yamashita M. 2008. Regulation of oocyte maturation in fish. Review. Development Growth Differentiation. 50 S: 159 -218 .

Patriche T. 2009. The importance of glucose determination in the blood of the cyprinids. Zootehnie si Biotehnologii, 42(2): 102106.

Piferrer F, Blázquez. 2006. Aromatase distribution and regulation in fish. Review Fish Physiology and Biochemistry 31(2): 215226.

Sudo R, Suetake H, Suzuki Y, Utoh T, Tanaka S, Aoyama J, Tsukamoto K. 2011. Dynamics of reproductive hormones during downstream migration in females of the Japanese eel, Anguilla japonica. Zoological Science, 25(1): 180-188.

Suetake H, Okubo K, Yoshiura Y, Aida K. 2003. GTH and GnRH molecules and their expression in the Japanese eel. In: Aida K, Tsukamoto K, Yamauchi K. (Eds.). Eel Biology. Springer-Verlag Tokyo. pp. 351372 .

Tomkiewicz J, Kofoed TMN, Pedersen JS. 2011. Assessment of testis development during induced spermatogenesis in the European eel Anguilla anguilla marine and coastal fisheries: dynamics, management, and ecosystem. Science, 3(1): 106-118.

Tsai Ya-Ju, Lee Mong-Fong, Chen Chia-Yung, Chang Ching-Fong. 2011. Development of gonadal tissue and aromatase function in the protogynous orange-spotted grouper Epinephelus coioides. Zoological Studies, 50(6): 693-704.

Tubio RIC, Pérez-Maceira J, Aldegunde M. 2010. Homeostasis of glucose in the rainbow trout (Oncorhynchus mykiss Walbaum): the role of serotonin. The Journal of Experimental Biology. 213(1): 18131821.

Uno T, Ishizuka M, Itakura T. 2012. Cytochrome P450 (CYP) in Fish. Review. Environ- 
mental Toxicology and Pharmacology, 34(1): 1-13.

Van Ginneken V, Dufour S, Sbaihi M, Balm P, Noorlander K, de Bakker M, Doornbos J, Palstra A, Antonissen E, Mayer I, van den Thillart G. 2007. Does a 5500-km swim trial stimulate early sexual maturation in the European eel (Anguilla anguilla L.)? Comparative Biochemistry and Physiology, Part A, 147: 1095-1103.

Van Ginneken V, Durif C, Dufour S, Sbaihi M, Boot R, Noorlander K, Doornbos J, Murk AJ, Van Den Thillart G. 2007a. Endocrine profiles during silvering of the European eel (Anguilla anguilla L.) living in saltwater. Animal Biology, 57(4): 453-465.

Van Ginneken V, Durif C, Balm SP, Boot R, Verstegen MWA, Antonissen E, Van den Thillart G. 2007b. Silvering of European eel (Anguilla anguilla): seasonal changes of morphological and methabolic parameters. Animal Biology, 57(1): 63-77.

Volkoff H, Unniappan S, Kelly SP. 2009. The endocrine regulation of food intake. In: Bernier NJ, Farrell AP, van der Krak G, Brauner CJ. (Eds.). Fish Physiology, 28: Fish Neuroendocrinology. Academic Press, London (UK). pp 421-465.

Weltzien F-A, Sébert M-E, Vidal B, Pasqualini C, Dufour S. 2009. Dopamine inhibition of eel reproduction. In: van den Thillart G, Dufour S, Rankin JC. (Eds.). Spawning migration of the European eel. Springer Science, London (UK). pp. 279-307.

Yaron Z, Levavi-Sivan B. 2011. Endocrine regulation of fish reproduction. Encyclopedia of fish physiology: From genome to environment, Vol. 2: 1500-1508. 
